Adam Węgrzecki

\title{
Doświadczenie obecności wartości w świecie
}

Pełniejsze zrozumienie roli wartości w życiu człowieka wymaga zastanowienia się nad tym, jak doświadcza on obecności wartości, czym stają się one dla niego. Wprawdzie wiąże się to z poznaniem wartości, ale bynajmniej nie sprowadza się do tego. Chodzi bowiem o coś więcej niż samo poznanie aksjologiczne, mianowicie o „pozycję”, jaką wartości uzyskują względem podmiotu osobowego, a także o to, jak on sam sytuuje się względem wartości.

Obecność wartości doświadczana jest na różne sposoby. Na szczególną uwagę zasługują dwa typy doświadczenia. Mówiąc ostrożniej, typy te uchodzą za doświadczenie, są niejednokrotnie traktowane jako doświadczenie. Mogą jednak nasuwać się wątpliwości, czy rzeczywiście dochodzi tutaj do głosu samo doświadczenie, czy ponadto nie pojawiają się pewne przeświadczenia o naturze wartości, mające nieempiryczny charakter.

Najbardziej charakterystycznym momentem doświadczenia pierwszego typu jest „obligujący charakter wartości”. Ich obecność jakby pociąga za sobą „powinność” czy „zobowiązanie”. Podmiot czuje, że w związku z ich pojawieniem się należy coś uczynić, np. stanąć w obronie pewnej wartości, postarać się, by znalazła ona pełny wyraz, udostępnić ją innym ludziom. Czuje również - przynajmniej niekiedy - że niczego nie czyniąc na rzecz wartości bądź wręcz podejmując działania przeciw wartości, jakby narusza ową „powinność”, owo „zobowiązanie”. W taki właśnie sposób podmiot doświadcza obecności wartości. Czym jednak 
jest ta ,powinność” czy to ,zobowiązanie”? Mogłoby się wydawać, że momenty te są bardzo podobne do siebie, ale zachodzą między nimi dość istotne różnice.

„Powinność”, czy dokładniej „powinnościowość istnienia”, stanowiłaby raczej - o ile dałoby się jeszcze ją potwierdzić w poznaniu aksjologicznym - moment natury wartości. Niekoniecznie należałoby przy tym przesądzać, że przysługiwałaby wszystkim rodzajom wartości. Powinnościowość istnienia oznaczałaby, że wartości „ciążą ku istnieniu". W przeciwieństwie do innych bytów istniejących w taki lub inny sposób, wartościom miałoby właśnie trwale przysługiwać owo „ciążenie”. Można by to interpretować w ten sposób, że wartość - jeszcze nie zaistniawszy - „powinna zaistnieć”, a więc ,przejść” do istnienia czy być ,przeprowadzona” w istnienie. Chodziłoby tu o zaistnienie wartości - jak powiedziałby Ingarden - in concreto i in individuo. Jednak nawet wtedy, gdy wartość już zaistniała, owa ,powinność” nie wygasa, gdyż wartość ,„powinna” móc istnieć nadal. Stwierdzenie to zachowuje swój sens, o czym zdaje się przekonany Nicolai Hartmann zauważając, iż „to, że człowiek «powinien» być rzetelny, szczery, godny zaufania, jest czymś, co nie zostało uchylone przez to, że ktoś faktycznie jest

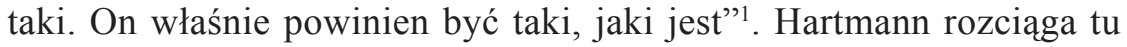
powinność na człowieka jako nosiciela pewnych wartości. Czyni to raczej z uwagi na podmiot jako instancję realizującą ,powinność”, która „pochodzi” od wartości, aniżeli ze względu na podmiot jako instancję, z której „pochodziłaby” powinność obejmująca swym zasięgiem wartości. Wówczas wreszcie, gdy wartość przestała istnieć, ,powinna” ona zaistnieć ponownie.

W każdym więc przypadku - nie wyłączając faktycznego istnienia - zostaje utrzymana ,powinnościowość istnienia” wartości, co przemawiałoby za tym, że jest ona istotnym rysem jej natury. „Powinnościowość istnienia" wykazuje przy tym jakiś pozaczasowy charakter. Nie ma przecież sensu mówić, że się ona w jakimś momencie „,zaczyna”, a w innym „kończy”. Toteż w zderzeniu z realnym upływem czasu oraz z przebiegającymi w nim działaniami konkretnego podmiotu osobowego każda chwila nieobecności wartości jawi się jako rażący jej brak. Dopiero uprzytomniwszy sobie ten szczególny rys natury wartości, podmiot

\footnotetext{
${ }^{1}$ N. H a r tm a n n, Ethik, wyd. 4, Berlin 1962, s. 171.
} 
osobowy mógłby poczuć się zobowiązany do tego, by zapewnić jej nieprzerwaną obecność, by starać się nie dopuścić do żadnej zwłoki i nie „odkładać”, na bliższą czy dalszą przyszłość, realizacji wartości. „Sama „powinnościowość istnienia” nie jest, jak się wydaje, wprost skierowana do człowieka. Toteż wymaga „odczytania” i przeżycia przez podmiot.

„Powinnościowość istnienia” wartości pozostaje w ścisłym związku z jej pozytywnością i materią, a może nawet z jej wysokością. Można by powiedzieć, że pewna wartość „,powinna istnieć” właśnie ze względu na to, iż jest taką wartością, ze względu na swoje określenie jakościowe. Jak powiada Józef Tischner, „,dobro jest tym, co z natury dąży do zaistnienia”2. „Odczytanie” powinnościowości istnienia wartości wymagałoby zatem uchwycenia jej pozytywności, a zwłaszcza jej jakościowego określenia. Może się to dokonać jedynie w szczególnym doświadczeniu, jakim jest doświadczenie aksjologiczne. Kto je więc neguje, może skłaniać się do poglądu, że przeświadczenie o powinnościowości istnienia wartości wynika z pewnych założeń metafizycznych. „Odczytanie” powinnościowości istnienia wartości mogłoby nastręczyć pewnych trudności, gdyby przyjąć, że powinnościowość ta nie przysługuje wszystkim rodzajom wartości. Oznaczałoby to bowiem, że nie przesądza o niej sama pozytywność wraz z jakościowym określeniem wartości. Wobec tego należałoby - o ile utrzymać przedmiotowy kierunek poszukiwań - w naturze samej wartości szukać takiego momentu, który dopiero decydowałby o powinnościowości jej istnienia. Można przypuszczać, że byłby to moment rodzajowy, właściwy np. wszystkim pozytywnym wartościom moralnym.

Natomiast „zobowiązywanie” - o ile traktować je jako szczególny rys samych wartości - właściwie nic nie mówiłoby o naturze wartości, zwłaszcza zaś o ich „ciążeniu ku istnieniu”. Zobowiązywanie jest odniesieniem do kogoś, kto byłby w stanie je podjąć i coś uczynić na rzecz wartości. Dopóki istnieje możliwość takiego działania, zobowiązywanie może znaleźć swoje wypełnienie.

Zarówno „powinnościowość istnienia”, jak i „zobowiązywanie” świadczyłoby o obligującym charakterze wartości. Gdyby owe momenty

2 J. T is c h n e r, Filozofia dramatu, Paryż 1990, s. 55. Dosłownie trudno byłoby przypisywać dobru lub wartościom jakieś dążenie. 
należały do ich natury, trzeba by uznać, że znalazłszy się w obliczu wartości, człowiek stawałby przed szczególnym ,zadaniem”. W każdym razie mógłby czuć się jakby „wezwany” do jego podjęcia i zrealizowania go w sposób czyniący zadość naturze rozmaitych wartości. Wówczas mogłoby się jednak wyłonić niepokojące pytanie o to, jakie są właściwie motywy działania podmiotu na rzecz wartości. Wydawałoby się, że odpowiedź jest prosta, że człowiekowi chodzi o wartości ze względu na ich cenność, wartościowość, która nadaje przedmiotowi - jak powiada Roman Ingarden - pewną dignitas ${ }^{3}$. Tymczasem jednak mogłoby się pojawić inne przypuszczenie, kierujące uwagę na zupełnie inny aspekt. Otóż trudno wykluczyć, że człowiekowi chodzi o wartości po prostu dlatego, że jest on przez nie w przemożny sposób obligowany. Trudno wykluczyć, że podmiotowe działania na rzecz wartości stanowią odpowiedź, w jakiejś mierze wymuszona, na owo zobligowanie.

Przypuszczenie to pozostaje w związku z pewnym rozumieniem „obligowania”. Można je bowiem, jak się wydaje, rozmaicie interpretować, dopuszczając jego postać słabszą oraz postać mocniejszą. Niekiedy przyjmuje się, że wartości obligują tak mocno, iż można by rzec, że wręcz ,zniewalają”, wywierają na człowieka „presję”. Krótko mówiąc, „oddziałują" nań w taki sposób, że trudno im się oprzeć. Stają się wówczas szczególną instancją normatywną czy imperatywną. Przy takim rozumieniu wartości, normy byłyby już zbędne, ponieważ właśnie wartości „przejmują" ich rolę. Takiego wydźwięku nabiera koncepcja Dietricha von Hildebranda - przynajmniej wtedy, gdy mówi on o „wzniosłym wołaniu”, o „wezwaniu” płynącym od wartości, ,by człowiek kierował się ich żądaniami i poddawał się ich prawom"4. Wydźwięk ten staje się jeszcze wyraźniejszy, gdy zauważa on, że światu wartości „obiektywnie przysługuje władza" nad człowiekiem ${ }^{5}$. Być może owe zwroty dałoby się potraktować jako szczególne figury retoryczne. Jeśli jednak brać je dosłownie, nie ulega wątpliwości, że w znaczeniu przyjętym przez Dietricha von Hildebranda wartości obligują w sposób przemożny.

${ }^{3}$ Por. R. Ingarde n, Czego nie wiemy o wartościach, [w:] t e nże, Przė̇ycie, dzieło, wartość, Kraków 1996, s. 100.

${ }^{4}$ D. von Hildebrand, Fundamentalne postawy moralne, [w:] te nże, J. A. Kł o c z o w s k i, J. P a ś c i a k, J. T is c h n e r, Wobec wartości, Poznań 1982, s. 13.

5 Tamże, s. 29. 
Koncepcja taka budzi opory z rozmaitych względów. Przede wszystkim sugeruje ona wyraźnie, że wartości miałyby jakoś działać czy oddziaływać na człowieka. W takim razie trzeba by przyjąć, że są one wyposażone $\mathrm{w}$ jakieś siły czy tendencje. Jednak nie wydaje się, aby w ten sposób można było sensownie orzekać o wartościach. Zakładałoby to bowiem dość szczególną ontologię wartości, ujmującą je jako byty, w których naturze leży działanie. Zdecydowanie przeciwstawia się temu Nicolai Hartmann:

Same wartości nie są źródłem żadnego determinizmu [...]. Wartości jako takie nie predestynują, nie przymuszają - zarówno osoby, jak innej istoty realnej [...]. Same z siebie wartości nie mają siły do tego, by poruszyć coś realnego. Siłę mogą uzyskać dopiero skądinąd, mianowicie jedynie ze strony realnej osoby, o ile ona za nimi się opowie (sich einsetzt). Oznacza to, że jeśli wartości w ogóle determinują, to z pomocą tej pozytywnej instancji ${ }^{6}$.

Jest to determinacja, która nie zachodzi niezależnie od podmiotu, lecz może się dokonać wyłącznie za jego pośrednictwem, przy jego udziale. Jest to determinacja dokonująca się nie na drodze faktycznego oddziaływania, ale - jak można by powiedzieć - poprzez materię wartości, poprzez jej jakościowe określenie. Wartość nie „oddziałuje” w tym sensie, że „skłania” podmiot osobowy do zwrócenia się na jej materię. Podmiot może, ale nie musi się zwrócić ku niej, może, ale nie musi uczynić coś więcej niż ją zauważyć, może, ale nie musi przy niej „pozostać”, mieć ją stale na uwadze i starać się ją uwzględniać w swych działaniach. Trudno zatem nie zgodzić się z Nicolai Hartmannem, gdy stwierdza, że „Wprawdzie wartości wykazują tendencję do determinacji teleologicznej, ale same z siebie nie determinują one w sposób rzeczywisty; wprawdzie domagają się pewnych celowych ukierunkowań woli, ale nie mają mocy, by ją przeprowadzić [...]. Natomiast wola ma moc opowiedzenia się za określonymi celami"’’.

Ponadto na gruncie takiej koncepcji wartości ograniczałyby w znacznej mierze swobodną aktywność podmiotu, ,dyktując” mu kierunki wyboru i działania. Nie można by już o wartościach powiedzieć, że są one aksjologicznym dopełnieniem możliwości otwierających się przed

\footnotetext{
${ }^{6}$ N. H a rt m a n n, dz. cyt., s. 770-771.

7 Tamże, s. 792.
} 
człowiekiem, który swobodnie poszukuje wyznaczników swej aktywności i swobodnie realizuje swoje zamierzenia. Wolność wewnętrzna podmiotu ulegałaby wówczas znacznemu zawężeniu. Wydaje się jednak, że ,determinacja przez wartości nie tylko nie jest hamulcem osobowej wolności, lecz raczej jest pozytywnie uwarunkowana przez nią"9 - o ile naturalnie nie uzna się, że wartości wywierają ,presję” na człowieka lub mają nad nim ,władzę".

Czy jednak nie doświadcza się obecności wartości jako czegoś, co właśnie wywiera „,presję” na podmiot osobowy? Czy nie odczuwa się, przynajmniej niekiedy, ich „władzy”? Fakty takie zapewne się zdarzają. Niekiedy wartości mogą rzeczywiście jawić się w przeżyciu w charakterze narzucającego się i zniewalającego. Ich pozycja nadrzędna wobec podmiotu zaznacza się wtedy tak wyraźnie, iż w swym poczuciu gotów jest on z całym posłuszeństwem poddać się ich ,wymaganiom”. Czy wobec tego należałoby uznać, że taka jest natura wartości? W każdym razie prezentują się one w taki właśnie sposób. Toteż w samym fenomenie może się nawet nie zaznaczać różnica między tym, co podmiot ewentualnie przypisał wartościom, w co je wyposażył, a tym, co faktycznie w ich naturze w doświadczeniu rozpoznał.

W obliczu tak doznawanych wartości aktywność podmiotu podlega ograniczeniu, gdyż sprowadza się do działań, w których czyni on zadość „wymaganiom” wartości. Na pierwszy rzut oka owo ograniczenie przedstawia się tak samo, jak wówczas, gdy ktoś z własnej inicjatywy oraz z całym oddaniem i poświęceniem działa na rzecz pewnej wartości. Zarówno w jednym, jak i w drugim przypadku odnoszące się do niej działania mogą być nawet identyczne. Jednak przypadki te zasadniczo różnią się między sobą. Zupełnie innej natury jest bowiem ograniczenie przyjmujące sam podmiot, które jest więc samoograniczeniem, wprowadzonym przez niego na gruncie wolności wewnętrznej, innej zaś natury jest ograniczenie pochodzące niejako ,z zewnątrz”. O ile pierwsze ograniczenie jest „wypracowane” przez podmiot osobowy, o tyle drugie ograniczenie jest mu przekazane jako zadanie, które winien po prostu zaakceptować.

${ }^{8}$ Ideę wolności wewnętrznej rozwijam w artykule Uwagi o wolności wewnętrznej (,Zeszyty Naukowe UJ” 1993, z. 9), a zwłaszcza w rozdz. 6 pracy Zarys fenomenologii podmiotu.

9 N. H artmann, $d z$. cyt., s. 771. 
Możliwe jest też innego typu doświadczenie obecności wartości. W tym doświadczeniu wartość jawi się nie w charakterze czegoś, co obliguje, co wywiera presję na podmiot, lecz jako coś cennego. Wartość pozytywna posiada - jak znamiennie zauważa Ingarden - „szczególny urok"10, dzięki któremu okazuje się ,atrakcyjna”, zwraca na siebie uwagę, niejako „przyciaga” podmiot do siebie. Wprawdzie to, czym różne wartości pozytywne ,przyciagają” podmiot, nie zawsze dałoby się określić jako „urok”, ale z pewnością jest to coś zupełnie innego niż przymus czy presja. Przedmiot roztaczający urok zupełnie nie narzuca się podmiotowi, nie ogranicza jego wolności wewnętrznej i nie pomniejsza zakresu stanowienia o sobie. „Wartość zdaje się mówić do mnie: «jeśli chcesz, możesz mnie wybrać» [...]. Podmiotem doświadczenia wartości jest podmiot wolny. Cały urok świata wartości bierze się zapewne stąd, że nic z tego świata nie narzuca się nam przemocą"11. Przemoc nie towarzyszy samym wartościom. Można by nawet powiedzieć, że ich obecność w jakiejś mierze osłania przed przemocą. Jeśli jednak w naszym życiu staną się one nieobecne, ,jeśli tego świata nie uznajemy - ostrzega Józef Tischner - możemy ulec jakiejś przemocy"12.

Gdyby zatem zgodnie z tym doświadczeniem obecności wartości uznać, że nie są one czymś z natury obligującym, to można by się również nie obawiać ich ograniczającego wpływu na wolność wewnętrzną. Podmiot osobowy w swych decyzjach, działaniach i czynach miałby na względzie takie czy inne wartości, w swej aktywności brałby je pod uwagę, liczyłby się ze swoistą naturą danej wartości, ale orientując się na wartości, pozostawałby całkowicie wolny, pozostawałby źródłem stanowienia o sobie. Jak ująłby to Scheller, wprawdzie treści chcenia są określone przez wartości, ale „,chcenie tak określonych treści pozostaje «wolne»"13. Zachowując wolność, podmiot osobowy wcale nie musi uchybić wartości, może w swym postępowaniu przyznać jej należne miejsce w stopniu nie mniejszym, aniżeli wtedy, gdy poddał się wartości z uwagi na jej obligujący charakter. Podmiot może - jak powiedział Józef

${ }^{10}$ R. In ga r d e n, O naturze ludzkiej, [w:] t e n ż e, Ksiażeczka o człowieku, Kraków 1975, s. 23.

11 J. T i s c h n e r, Myślenie wedtug wartości, Kraków 1982, s. 485-486.

12 Tamże, s. 486.

13 M. S c h e l e r, Problemy religii, przeł. A. Węgrzecki, Kraków 1995, s. 177. 
Tischner - uczynić wartości „partyturą swego bytowania”14. Zapewne istnieje wówczas nieco większe ryzyko, że nie nastąpi owa „szczę́liwa” koincydencja znacznej, a w każdym razie nienaruszonej przez wartości, wolności wewnętrznej oraz faktycznej obecności wartości w postępowaniu. Być może, zważywszy na słabość człowieka, ułomność jego natury, rodzi się niejednokrotnie myśl, by wesprzeć go odpowiednio mocno i jednoznacznym zobowiązaniem do takiego, a nie innego postępowania, płynącym choćby z natury wartości. Chodziłoby tu już raczej o skuteczność wprowadzania wartości w życie człowieka, o ewentualne ,wzmocnienie" doświadczenia przez powołanie się na takie zobowiązanie. Bez niego podmiot może także liczyć się - zachowując przy tym własną inicjatywę - z daną wartością w różnych sytuacjach i okolicznościach, upatrując w niej aksjologiczne dopełnienie własnego działania. Jego niedeklaratywna aprobata danej wartości, znajdujące odzwierciedlenie w jego aktach uznanie jej ,atrakcyjności”; rodzą się one na gruncie wolnego wyboru i „moga” zostać wycofane. Owa „możność” wskazuje tylko na to, że ciagle pozostaje to w gestii podmiotu osobowego. Nie oznacza zaś bynajmniej tego, że aprobata i uznanie mogą pojawiać się i znikać z jakichkolwiek względów, że są wyrazem np. przelotnych nastrojów i upodobań podmiotu. Jeśli jednak tak się dzieje, to można sądzić, że jeszcze się nie ukształtowała w nim pewna orientacja aksjologiczna, która m. in. chroni go przed dowolnością i samowolą. Dopiero bowiem orientacja aksjologiczna stanowi swego rodzaju drogowskaz w życiu podmiotu osobowego. Gdy orientacja ta istnieje, poszczególne decyzje i działania człowieka są jej „,bliskie” w sensie aksjologicznym. Co prawda, nawet wówczas może się zdarzyć, że jakieś działanie mające podmiotowy charakter okaże się całkowitym odstępstwem od niej? Jednak rozpoznanie w nim błędu i ponowne ,przybliżanie się” do orientacji aksjologicznej bynajmniej nie pozwala stwierdzić, że w życiu podmiotu osobowego zapanował chaos, że faktycznie przestał on stanowić o sobie, zdając się na chwilowy impuls wewnętrzny lub przypadkowe zdarzenie zewnętrzne.

Istnienie odmiennych sposobów doznawania obecności wartości skłania do ogólniejszej refleksji. Za czym właściwie zdają się one przemawiać? Czy tylko za ewentualnym typologicznym zróżnicowaniem

${ }_{14}$ J. T i s c hn e r, Egzystencja i wartość, [w:] te n ż e, Świat ludzkiej nadziei, Kraków 1975, s. 200. 
podmiotów osobowych, które na skutek różnych losów życiowych, zwłaszcza zaś rozmaitych oddziaływań wychowawczych, tak odmiennie doświadczają obecności wartości? Może wobec tego należałoby po prostu odwołać się do teorii podmiotu oraz poddawszy szczególnej interpretacji pojęcie „doświadczenia”, uwydatnić w nim rolę takiej czy innej struktury podmiotowej, która spychałaby na dalszy plan to, co dane. Wówczas mogłoby się nasunąć przypuszczenie, że pewne struktury podmiotowe bardziej ingerują w doświadczenie, inne zaś słabiej lub w znikomym stopniu. W pierwszym przypadku doznanie obecności wartości byłoby wypadkową doświadczenia i ingerencji tego rodzaju. W drugim natomiast - w doznaniu dominowałoby doświadczenie. Z uwagi na to zróżnicowanie oba sposoby doznawania obecności wartości nie byłyby równie źródłowe w sensie przedmiotowym. W jednym z nich dochodziłaby do głosu silna projekcja ze strony podmiotu. Trzeba przy tym pamiętać, jak wielokrotnie podkreślał Ingarden, że rozstrzygnięcie wielu kwestii aksjologicznych - nie wykluczając kwestii doświadczenia wartości - może wyglądać różnie w zależności od rodzaju wartości ${ }^{15}$.

15 Sam Ingarden uważał, że ,„powinnościowość” zaistnienia wartości moralnych jest „,bezwzględna”, podczas gdy w przypadku wartości estetycznych „tego rodzaju powinnościowość istnienia nie zachodzi” (R. I n g a r d e n, Czego nie wiemy..., s. 91). 